\title{
Flexural Test of Fly Ash based Geopolimer Concrete Beams
}

\author{
Nindyawati ${ }^{1,2,{ }^{*}}$, Sri Umniati B. ${ }^{1,2}$, and Puput Risdanareni ${ }^{1,2}$ \\ ${ }^{1}$ Department of Civil Engineering, Universitas Negeri Malang, Malang, Indonesia \\ ${ }^{2}$ Konsorsium Riset Geopolimer Indonesia (KORIGI), Lab Beton dan Bahan Bangunan ITS, Surabaya, \\ Indonesia
}

\begin{abstract}
Fly ash is a by-product from the coal industry, which is widely available in Indonesia. Fly ash contains quite high silicate and alumina. Silica and alumina reacts with alkaline solution to produce alumina silicate gel which binds the aggregate to produce geopolymer concrete. Geopolymer concrete is introduced as an environmental concrete with high compressive strength. The use of geopolymer concrete beams is a solution to reduce the effects of greenhouse gases. This research uses experimental designs. The data are obtained from the testing of 4 pieces of reinforced geopolymer concrete beams and reinforced ordinary concrete beams with a / $\mathrm{d}$ of 1.11 and 2.24. The results are obtained from the maximum load that can be accepted by the beam. The results of this study are: (1) Geopolymer concrete cylinder has $26.78 \%$ higher compressive strength than ordinary concrete cylinders (2) Ordinary concrete beams can withstand $34.8 \%$ load higher compared to the geopolymer concrete beam (3) Reinforced ordinary concrete beams experience bending shear collapse while reinforced geopolymer concrete beam experience pure bending collapse.
\end{abstract}

\section{Introduction}

Concrete is the most popular construction material. The benefits are reduction in the use of cement to reduce air pollution and improve the propertiess of concrete. In the cement factory, every ton of Portland cement produces about one ton of $\mathrm{CO} 2$ in the atmosphere [1]. The replacement alternatives for cement are fly ash, silica fume, rise husk ash, metakaolin, or a combination of the above materials. Silicate and alumina are rich in fly ash and hence reacts with alkaline solution to produce alumina silicate gel that will be formed as geopolymer concretes.

Indonesia is a coal producing countryy. The coal is used in electricity generatingg fuel. One of the material produced by the burning power plants are fly ash. The abundant sources of fly ash can be utilized for the geopolymer concrete production.

Based on previous study by Rangan, the geopolymer concrete beams with widths of 200 $\mathrm{mm}$, a height of $300 \mathrm{~mm}$ and a length of $3300 \mathrm{~mm}$ beam using reinforcement $12 \mathrm{~mm}$ by 4 units with $150 \mathrm{~mm}$ spacing between reinforcement, reinforcement ratio of $0.64 \%-2.69 \%$ were made. The cylinders generated compressive strength of $550 \mathrm{MPa}-560 \mathrm{MPa}$ while

\footnotetext{
* Corresponding author: nindyawati.ft@um.ac.id
} 
beams generated ultimate momen of $168.7 \mathrm{KNm}$ [2]. In addition, crack pattern of beams was highly influenced by shear span (a) and effective high (d) of the beam.

Geopolymer Concrete thin-Webbed T-Beams with a size of $250 \mathrm{~mm} \times 300 \mathrm{~mm}$ and has a/d value of 1.5 and a/ $d$ of 2 experience bending collapse behavior [1]. The maximum moment of geopolymer concrete beams with a/d of 1.5 and a/d of 2 are $211.97 \mathrm{KNm}$ and 233.29 $\mathrm{KNm}$.

This study is comparing the flexural load on geopolymer concrete beams and ordinary concrete beams. Variations a/d beams of $=1.11$ and $\mathrm{a} / \mathrm{d}=2.24$ was used. Hence, compressive strength of ordinary and geopolymer concrete was also compared.

\section{Materials}

Cement. Pozollan Portland Cement conforming to Standard Nasional Indonesia is used in the present investigation of specific gravity 3.12.

Fly ash. Fly ash used in this study was obtained from Paiton Power Corporation, East Java Indonesia and the specific gravity of fly ash is 2.14 .

Aggregates. The locally available river sand of zone III was used as fine aggregate in the present in Tabel 1. The properties of aggregate used specific gravity of fine and coarse aggregate -2.66 and 2.70, fineness modulus of fine and coarse aggregate -2.43 and 6.71

Concrete. In this study, geopolymer concrete mix design compressive strength plan of $44 \mathrm{MPa}$ was used. In addition, ordinary concrete using DOE (Degree Of Environment) with a compressive strength plan of $35 \mathrm{MPa}$. Adding margin value of 8,5 Mpa at DOE mix design calculation was conducted in order to adjust ordinary and geopolymer concrete compressive strength plan [3]. Futhermore, compressive strength plan of ordinary concrete was 43.5 MPa. The mix proportion of geopolymer and ordinary concrete is presented in Table 1.

Table 1. Mix Proportion of Concrete

\begin{tabular}{|c|c|c|c|c|c|c|c|}
\hline \multirow[t]{3}{*}{ Description } & \multicolumn{6}{|c|}{ Quantity } & \\
\hline & \multicolumn{2}{|c|}{ Cylinder } & \multicolumn{2}{|c|}{ *AD11 } & \multicolumn{2}{|c|}{ *AD22 } & \\
\hline & $* \mathrm{~B}$ & $* \mathrm{G}$ & $*^{*} \mathrm{~B}$ & $* \mathrm{G}$ & ${ }^{*} \mathrm{~B}$ & $* \mathrm{G}$ & \\
\hline Cement & 2,21 & - & 0,77 & - & 1,35 & - & $\mathrm{kg}$ \\
\hline Fly Ash & - & 0,65 & - & 0,36 & - & 0,62 & $\mathrm{~kg}$ \\
\hline Fine aggregates & 2,84 & 0,44 & 0,99 & 0,24 & 1,73 & 0,42 & $\mathrm{~kg}$ \\
\hline Coarse aggregates & 4,49 & 0,88 & 1,57 & 0,48 & 2,74 & 0,84 & $\mathrm{~kg}$ \\
\hline Water & 1 & - & 0,35 & - & 0,61 & - & $\mathrm{kg}$ \\
\hline $\mathrm{NaOH}$ & - & 0,08 & - & 0,04 & - & 0,07 & $\mathrm{~kg}$ \\
\hline $\mathrm{Na}_{2} \mathrm{SiO}_{3}$ & - & 0,15 & - & 0,08 & - & 0,15 & $\mathrm{~kg}$ \\
\hline Superplasticziser & - & 0,01 & - & 0,007 & - & 0,01 & $\mathrm{~kg}$ \\
\hline
\end{tabular}

Description :

* B: Ordinary Concrete

* G: Geopolymer Concrete

* AD11: Beams with a / d = 1.11

* AD22: Beams with a / $d=2.24$

Alkaline Liquid. Alkaline activators made the day before use by mixing $\mathrm{NaOH}$ with aquades thus concentrating $10 \mathrm{M}$. The solution was mixed with $\mathrm{Na}_{2} \mathrm{SiO}_{3}$ with ratio between $\mathrm{Na}_{2} \mathrm{SiO}_{3} / \mathrm{NaOH}$ is 2 . 
Mixing and Casting. All the materials were measured, ie fly ash, gravel and sand. Fly ash, gravel and sand mixed into the mixer, and mix for 3 minutes. Then alkaline activator and superplasticziser liquid naphthalene sulphonate were added and stirred for 4 minutes until a homogeneous mixture blended. After the concrete mix homogeneous then the mixture can be removed from the mixer and moulded in a tub. Slump test was performed in accordance with (ASTM C 143-78). Fresh geopolymer concrete was moulded and compacted in the formwork using vibrator. This is treatment was conducted in order to produce good fresh concrete mixture and to reduce open pore of concrete.

Specimen Details. Four numbers of reinforced concrete beams with span of $800 \mathrm{~mm}$, wide of $50 \mathrm{~mm}$ and hight of $100 \mathrm{~mm}$ were produced. Beams were placed at simple suppot with an effective span of $700 \mathrm{~mm}$. The clear cover of the beam was $8 \mathrm{~mm}$. The spesimens was produced from two types of concrete that are geopolymer concrete and ordinary concrete. The beams are designed as under reinforced concrete. Specimen details are presented at Table 2 and Fig 1.

Table 2. Specimen Details

\begin{tabular}{|c|c|c|c|c|c|c|c|}
\hline $\begin{array}{c}\text { Beams } \\
\text { Code }\end{array}$ & Explanation & $\mathbf{a} / \mathbf{d}$ & b & $\mathbf{h}$ & $\mathbf{L}$ & $\varnothing$ reinforcement & $\begin{array}{c}\varnothing \\
\text { stirrups }\end{array}$ \\
\hline & & & $\mathbf{m m}$ & $\mathbf{m m}$ & $\mathbf{m m}$ & $\mathbf{m m}$ & $\mathbf{m m}$ \\
\hline BB11 & Normal Concrete & 1.11 & 50 & 100 & 800 & 4,4 & $2,5-25$ \\
\hline BG11 & $\begin{array}{l}\text { Geopolimer } \\
\text { Concrete }\end{array}$ & 1,11 & 50 & 100 & 800 & 4,4 & $2,5-25$ \\
\hline BB22 & Normal Concrete & 2,24 & 50 & 100 & 800 & 4,4 & $2,5-35$ \\
\hline BG22 & $\begin{array}{l}\text { Geopolimer } \\
\text { Concrete }\end{array}$ & 2,24 & 50 & 100 & 800 & 4,4 & $2,5-35$ \\
\hline
\end{tabular}

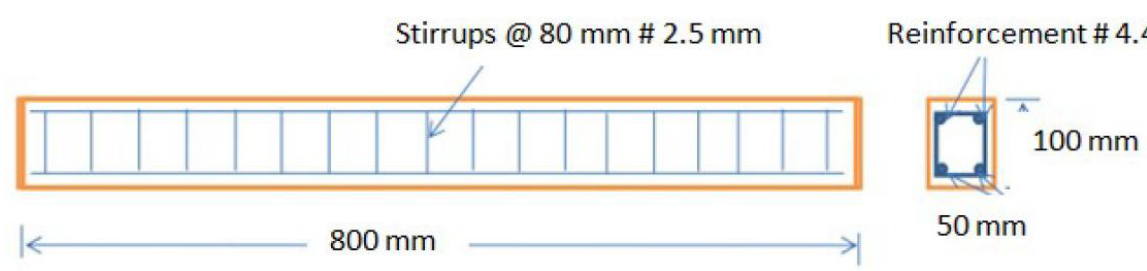

Fig. 1. Specimens Details

The beams were simply supported over a span of $700 \mathrm{~mm}$. The load was applied on two point each: $100 \mathrm{~mm}(\mathrm{a} / \mathrm{d}=1.1)$ and $200 \mathrm{~mm}(\mathrm{a} / \mathrm{d}=2.2)$ away from the support. The beams were subjected to two-point loads under load control mode. The load was applied in increment $2 \mathrm{kN}$. Dial gauge was placed in the midspan beam bottom. The gauge was used for measuring deflections. Dial gauge of $0.001 \mathrm{~mm}$ readings are recorded at increment loads. The movement of the beam was observed carefully. 


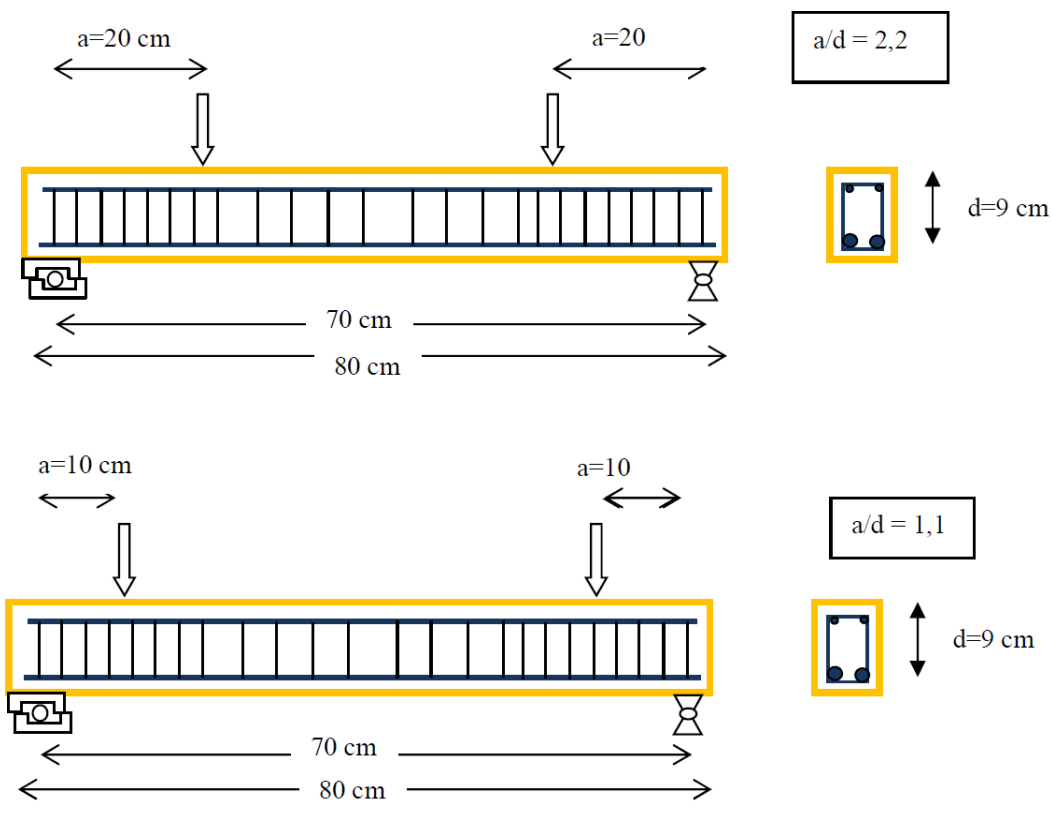

Fig. 2. Set Up Loading

\section{Result and discussion}

Compressive Strength of Concrete. Compressive strength of geopolymer and ordinary concrete was shown at figure 3 . The results show that compressive strength of geopolymer concrete is higher than ordinary concrete. The average compressive strength of ordinary concrete cylinders is $24 \mathrm{Mpa}$. The average compressive strength of geopolymer concrete cylinders is $31 \mathrm{Mpa}$. Compressive strength of geopolymer concrete is $26.78 \%$ higher than ordinary concrete.

Geopolymer concrete and ordinary concrete compressive strength decreased from its plan. Geopolymer concrete compressive strength plan is $31 \mathrm{MPa}$ while ordinary concrete compressive strength is $24.41 \mathrm{MPa}$. The first factors that predicted led the decreasing compressive strength of geopolymer concrete and ordinary concrete is the less flat of concrete surface specimens. The smoothing surface of concrete cylinder can improve the strength of concrete by $1 \%-21 \%$ [4]. Porosity of concrete was also predicted to be another factor that led decreasing strength of concrete. Previous research stated that the higher porosity percentage of concrete, the lower compressive strength owned [9].

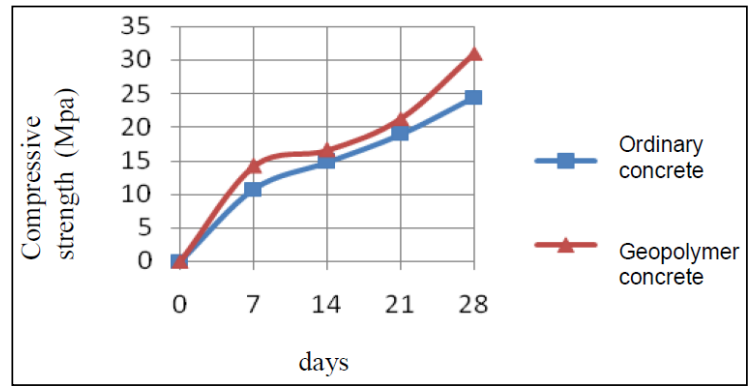

Fig. 3. Compressive strength of concrete in different age 
Beams Deflection. Ultimate load and maximal deflection of beams was presented at table 3, while load versus deflection curve was illustrated at figure 4. BG11 and BG22 are expected to have higher bending force than BB11 and BB22 but this study revealed different result. It can be seen at table 3 that BB11 and BB22 which was produced from ordinary concrete has higher ultimate load capacity than BG 11 and BG 22 which was produce from geopolymer concrete. Beam type BB 22 has the highest ultimate load compare to other specimens with the value of $13 \mathrm{kN}$. In addition, beam BB22 has the smallest deflection with value of $0.16 \mathrm{~mm}$.

Table 3. Ultimate Load and Maximum Deflection of Beams

\begin{tabular}{|l|c|c|c|}
\hline Beams Code & \multicolumn{1}{|c|}{$\begin{array}{c}\text { Ultimate Load } \\
\text { (kN) }\end{array}$} & \multicolumn{2}{c|}{ Max. Deflection (mm) } \\
\hline BB11 & 11.6 & 0.094 \\
\hline BG11 & 8.6 & 0.06 \\
\hline BB22 & 13 & 0.182 \\
\hline BG22 & 5 & 0.16 \\
\hline
\end{tabular}

At figure 4 it can be seen that ordinary concrete beam has higher flexural strength than geopolymer concrete beams. This result is little bit different from author expectation, geopolymer beams expected to higher flexural strength than ordinary concrete due to its high compressive strength. This unexpected result occurs because geopolymer concrete beams are more brittle than ordinary concrete beams.

The stiffness of ordinary and geopolymer concrete can be determined from its elasticity modulus value. Higher elasticity modulus value will deliver brittle characteristic of the concrete. This result has a good agreement with research conducted by Datatreya, that geopolymer concrete has higher modulus of elasticity (Ec) than ordinary concrete [6].

Differences load serviceability between BB11 and BG11 or BB22 and BG22 was also caused by the lower flexural strength of geopolymer concrete compared to ordinary concrete. Ordinary concrete beams have higher flexural strength than geopolymer concrete although geopolymer concrete has higher compressive strength [7]. Differences in the bending moment on geopolymer concrete beams and concrete beams was also caused by low capacity strength absorption of geopolymer concrete beams. The capacity strength absorption of geopolymer concrete beams affecting its moment result, the lower capacity strength absorption of the beam, the lower moment capacity owned [3].

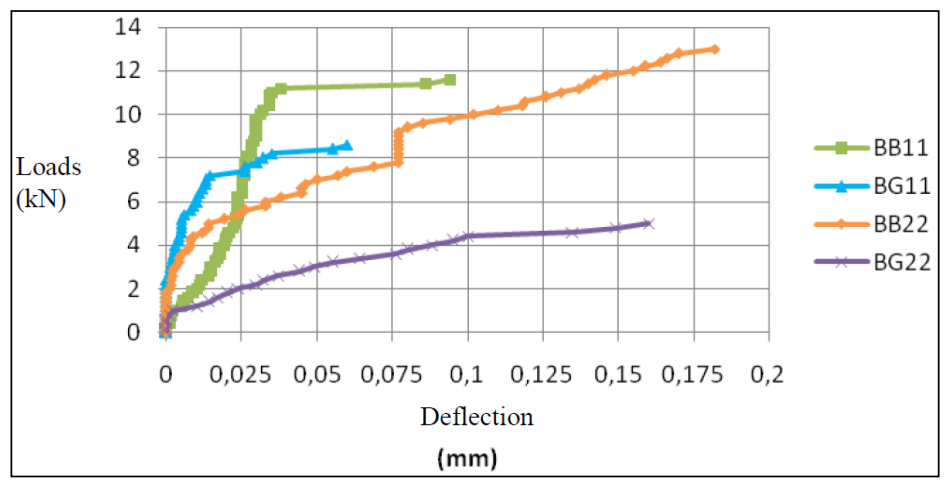

Fig. 4. Load and Deflection Curve 
Crack Pattern. Crack patern of geopolymer and ordinary concrete beams was presented at figure 5 and 6 . Pure flexural failure is characterized by a vertical crack which occurs only in the middle of the beam span. At figure 5 it can be seen that ordinary concrete beam with $\mathrm{a} / \mathrm{d}$ variation of $1-2.5$ bending collapse mostly occurs than shear collapse. The bending collapse occurred because the bond between geopolymer binder with ageregat is more solid compared to cement ties with aggregate in ordinary concrete. This condition led geopolymer concrete to spalling easly than normal concrete. The solid bond between binder and agregate at geopolymer concrete led to the brittle characteristic of its concrete, thus the crack pattern of the beams only occurs at mid span . This result is apropriate with previous research by Sumanjauw which is stated that geopolymer concrete has high compressive strength than ordinary concrete [8].

Referring to the previous research, it can conclude that the BB11 and BB22 has bending shear collapse while BG11 and BG22 has pure bending collapse. This condition occurs because geopolymer has more solid bond with aggregate than ordinary concrete [6].

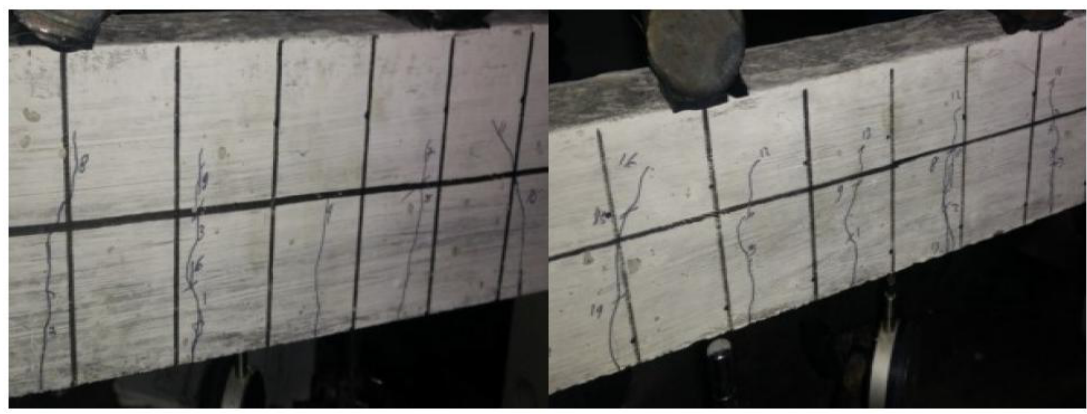

Fig.5. Crack pattern of Ordinary Concrete Beams (BB11 and BB22)

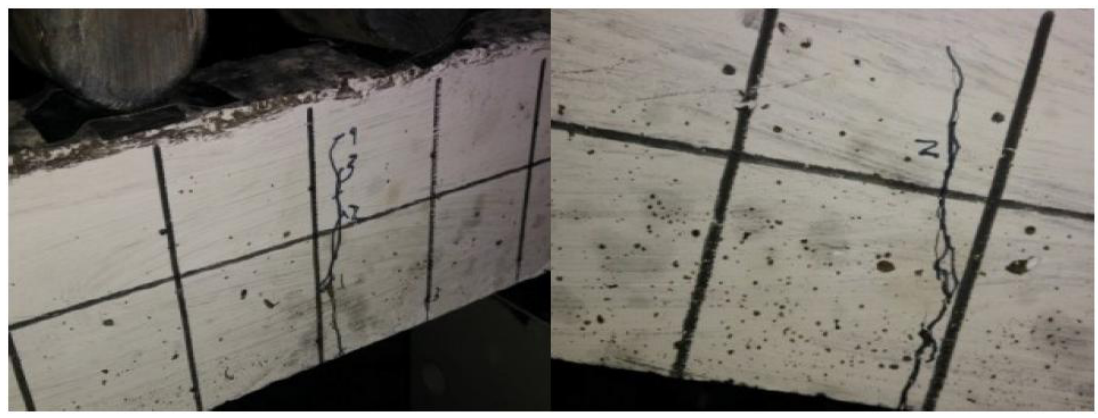

Fig.6. Crack pattern of Geopolymer Concrete Beams (BG11 and BG22)

\section{Summary}

From experimental investigation of study flexural test of fly ash based geopolymer concrete beams the following conclusion can be made :

1. Geopolymer cylinder concrete has $26.78 \%$ higher compressive strength than the ordinary concrete cylinder.

2. BB11 has $34.8 \%$ higher load capacity than BG11 while BB22 has $160 \%$ higher load than BG22. This condition occurs because the flexural strength of geopolymer concrete is lower than the ordinary concrete. 
3. BB11 and BB22 experience bending shear collapse, while BG11 and BG 22 experience bending collapse because geopolymer concrete bond is more solid compared to ordinary concrete bond.

This work was financially supported by Kementrian Riset, Teknologi, dan Pendidikan Tinggi (Hibah Bersaing).

\section{References}

1. C. K. Madheswaran, P. S. Ambily, N. Lakshmanan, J. K. Dattatreya, S. A. Jaffer Sathik, ACI Mater. J., 11(1), 89 (2014)

2. V. B. Rangan, D. Sumanjouw, S. Wallah, D. Hardjito, $31^{\text {st }}$ Conference on Our World In Concrete \& Structure (2006)

3. J. Davidovits, Special Publication, 144, 383 (1994)

4. K.D. Sushil, K.A. Sajal, Z.M. Abu, H.M. Mosaddek, D. Giash, Effect Capping System on Compressive Strength of Concrete (ICETCESD 2012)

5. Z.F. Farhana., H. Kamarudin, R. Azmi, A.M. Mustafa A.B, Key. Eng. Mater. 549-595 (2012)

6. J.K. Dattatreya, N.P. Rajamane, D. Sabitha, P.S. Ambily, M.C. Nataraja, International Journal of Civil And Structural Engineering, 2(1), 138 (2011)

7. E. Suryawangi, Y. Takarendehang, D. Hardjito, Jurnal Dimensi Pratama Teknik, 2(1), 1 (2013)

8. J.R. Yost, A. Radlinska, S. Ernst, M. Salera, N.J. Martignetti, Mater. Struct., 46(3), 449 (2013)

9. X. Chen, W. Huang, J. Zhou, Indian J. Eng. Mater. Sci., 19(6), 427 (2012) 